\title{
A Systematic Review of Low Level Laser (LLLT) Therapy on Pain Following Orofacial Surgeries
}

\author{
RADWA R. KHALAF, M.Sc.; WAFAA H. BORHAN, Ph.D. and NESRIN A. ABED EL RASHID, Ph.D. \\ The Department of Surgery, Faculty of Physical Therapy, Cairo University, Egypt
}

\begin{abstract}
Background: Oral Mucositis (OM) is still a common and severe acute side-effect of many oncologic treatments, especially in patients treated for head and neck cancer. It may affect quality of life, require supportive care and impact treatment planning and its efficacy. Low-Level Laser Therapy ( LLLT) seems to promote pain relief and reduces OM incidence and its severity. It has been recommended for these patients as a treatment option but without any consensus in the LLLT procedure. New recommendations and perspectives for clinical trials will be discussed.
\end{abstract}

Aim of Study: The aim of this systematic review was to examine the effectiveness of low level laser therapy on pain following oraofacial surgeries patients.

Material and Methods: Systematic Review of randomized controlled trials, data bases searched were made in Pubmed, Pedro, Google scholar and Cochrane, all studies were from 1996 to 2018. Limits were English language. Included studies were independently reviewed for methodological quality and assigned a level of evidence (Center for Evidence Based Medicine).

Intervention: Twelve relevant randomized controlled trials included the low level laser such as $\mathrm{He} \mathrm{Ne}$, GA As and LED and its effects on pain in patients with oraofacial surgeries.

Results: Twelve studies were selected, included in metaanalysis for the primary outcomes as mucositis and secondary outcomes as, ROM and quality of life.

Conclusions: Prophylactic LLLT "GaALAs" reduced severe mucositis and pain in post-operative oraofacial surgeries. there are some evidence support its effect on secondary outcomes as ROM, cognitive function, and quality of life.

Key Words: Low level therapy - Orofacial surgery - Laser mechanism - Laser parameters - He Ne - Pain - GaALAs - LED with associated mesh terms.

\section{Introduction}

EVIDENCE-Based Practice (EBP) is viewed as a mix of a learning what treatments "work" based

Correspondence to: Dr. Radwa R. Khalaf, The Department of Surgery, Faculty of Physical Therapy, Cairo University, Egypt on the best available research (whether experientialor not):

A- Discussing client views about the treatment to consider cultural and other differences, and to honor client self-determination and autonomy, considering the professionals "clinical wisdom" based on work with similar and dissimilar cases that may provide context for understanding the research evidence.

B- Considering what the professional can and cannot, provide fully and ethically [1].

Drisko and Grady [2] argued that EBP, as summarized by researcher, may devalue non experimental research, also argue that EBP is establishing a hierarchy of systematic reviews may concern clinical tests, public health interventions, social interventions adverse effects and economic evaluations [3].

A systematic review uses an objective and transparent approach for research synthesis, with the aim of minimizing bias. While many systematic reviews are based on an explicit quantitative metaanalysis of available data, there are also qualitative reviews which adhere to the standards for gathering, analyzing and reporting evidence [4].

According to Abdelghaffar et al., [5], Randomized Controlled Trial (RCT) is considered the gold stander of clinical research. It is the method of choice to compare and study therapeutic interventions and diagnostic tests.

The gold standard for testing theory-based interventions effectiveness is RCT. The systematic review or meta-analysis of RCT is considered to be the strongest evidence [6].

A systematic review of the effects of low level laser therapy on pain following oraofacial cancer 
patients and survivors concluded that laser has analgesic features that reduce pain and inflammatory mediators.

So, the aim of this study is systematically review the effect of low level laser therapy on pain in oraofacial cancer patients.

The primary obligations and ultimate responsibility of Boral healthcare providers is not only to restore function, but also to relieve pain. All orofacial surgical procedures produced secondary effects such as pain, swelling, and limitation of motion of which depending on the degree of tissue damage. Despite many advances in the provision of pain service, acute pain after surgery remains a serious cause of severe suffering $\left[{ }^{7}\right]$.

All surgical procedures produced secondary effect such as pain and swelling, the intensity of which depending on the degree of the tissue damage

Orofacial dysfunction has been defined as a collective term used to describe pain and dysfunction that involve the mastictory muscles, the temporomandibular joint, and the associated structures

The application of low energy laser in the field of dentistry and oral surgery has been described since the 1970s. Low energy laser light was supposed to reduce pain, to accelerate wound healing and to have a positive effect on inflammatory process [10].

Low power lasers are a group of lasers with power less than $250 \mathrm{mw}$. These lasers have analgesic features with their ability to trigger reactions that reduce pain and inflammatory mediators. Due to these features they have been used in the treatment of orofacial pain, including tooth hypersensitivity, post-operative flare-ups, mucositis, facial myalgia, temporomandibular joint disorders and neuralgia [11].

\section{Material and Methods}

\section{Literature search:}

A Literature Search was Performed on Baseline Pedro PubMed Google Scholars and Cochrane Controlled Trial Register.

Methods used to carry out this systematic review of existing evidence studies the effects of different types low level laser ( $\mathrm{He} \mathrm{Ne}, \mathrm{Ga}$ As and LED) therapy on pain following orofacial surgeries requirements for reports of systematic reviews and meta-analysis.
Randomized controlled trials of different types of low level laser therapy on pain following orofacial surgeries in this systematic review published from (1997-2018) were considered.

The review will included patients with oral cavity cancer aged from 12 to 94 years this review included randomized controlled trials studies which demonstrated the effects of different types low level laser ( $\mathrm{He} \mathrm{Ne}, \mathrm{Ga}$ As and LED) therapy on pain following orofacial surgeries with reported findings for analysis of its effectiveness.

This systematic review including different types of low level laser (He Ne, Ga As and LED) therapy on pain following orofacial surgeries.

\section{Inclusion criteria:}

The randomized controlled trials were subjected to the following six inclusion criteria:

1- Diagnosis: Oral mucositis in cancer patients induced after chemotherapy or radiation therapy.

2- Treatment: LLLT with wavelengths of 632$1,064 \mathrm{~nm}$,

3- Design: Randomized parallel group design or crossover design.

4- Blinding: Outcome assessors should be blinded.

5- Control group: Receiving identical placebo laser.

6- Specific endpoints for prevention of oral mucositis above a certain grade, oral mucositis severity, duration in days, and pain intensity.

\section{Outcome measures:}

1- The Relative Risk (RR) over placebo for preventing occurrence of oral mucositis above a certain grade (0-2) with LLLT.

2- The effect of LLLT on the severity of oral mucositis measured by the Oral Mucositis Index ( OMI) or WHO scales were calculated as the SMD versus placebo.

3- The effect of LLLT on the duration of days oral mucositis was calculated as the weighted mean difference versus placebo.

4- The effect of LLLT on pain intensity was calculated as the Standardized Mean Difference ( SMD) versus placebo and labeled after Cohen [ 21] as "poor" (0.2-0.5), "good" (0.5-0.8), or “ very good" (>0.8).

5- Subgroup analyses were planned for (1) doses of $<1 \mathbf{J}$ and $>1 \mathbf{J}$ (minimum dose according to 
WALT guidelines for other inflammatory conditions), (2) red and infrared wavelengths with their anticipated optimal dose ranges (1-4 J for red wavelengths and 3-8 $\mathrm{J}$ for infrared wavelengths).

\section{Study selection:}

After employing the search strategy described above all the studies meeting the inclusion criteria were identified and full-text reports of all relevant trials were obtained and assessed. Excluded studies and reasons for exclusion were stated.

This systematic review analyzed twelve randomized controlled trials, by applying strict selection criteria for inclusion, only full text articles of randomized controlled trials were included all trials met at least five criteria on the PEDro scale.

From all, eleven studies included all studies fulfill the criteria of high methodological quality which judged as strong ("yes" on 6-9 questions) according to PEDro scale.

\section{Data extraction:}

Data from all the included studies would be summarized in the following format that included: Participants' characteristics (number in each group, target population, diagnosis, numbers in each diagnostic subgroup, and ages), intervention used, research design and level of evidence for the study, and outcomes of interest. Data were extracted directly from the original articles.

Two observers (Prof. Dr.: Wafaa Hussein Borhan) and (Assist. Prof. Dr: Nesrin Afify Abed El Rashid) extracted data from the original papers that were included in this review using a standard extraction form; disagreements were discussed by the two review authors until a consensus was reached.

\section{The following data were extracted:}

- Study design.

- The characteristics of participants.

- The characteristics of interventions including types of laser, intensity, duration, modality, number of session per week, total duration (wks) and any additional care.

- Details of outcome measures.

- Risk of bias including randomization, blinding, attrition and reporting.

Assessment of risk of bias of included studies: The review authors independently assessed risk of bias of included studies, based on the Cochrane Handbook for Systematic Reviews of Interventions [12].

\section{Quality assessment of methodology:}

Pedro scale: Methodological quality for selected studies was assessed independently by two review authors using Physiotherapy Evidence Database ( Pedro) scale. It was more specific scale used to measure the quality of RCTs related to physical therapy interventions, so it was also used to assess quality of studies included in this review. The 11 criteria of Pedro scale.

The first item on the PEDro scale (the item on eligibility criteria) is related to external validity, it does not reflect the dimensions of quality assessed by the Pedro scale. This item was not used to calculate the method score (which is why the 11 item scale gives a score out of 10). According to the Pedro guidelines, a positive answer to each of the criteria 2 to 11 would yield one point. Obtaining a between 0 to 10 . The PEDro scale has been shown to have moderate interrater reliability (intraclass coefficient for the total score is $0.56,95 \%$ Confidence Interval [CI] 0.47-0.65) [13]. The Pedro scale includes the four features known to minimize bias in clinical trials (i.e. randomization, concealed allocation, blinding, and minimizing the dropout rate, and the remaining items have face validity [14].

Papers that had a Pedro score of seven or higher, would be considered 'high quality', those with a PEDro score of five or six would be considered ' moderate quality', and those with a PEDro score of four or less would be considered 'poor quality'. The more the number of scores of the aspects evaluating the quality of the study, the more quality of the study [15].

\section{Data analysis:}

After extracting data from each study included in this systematic review data were compared and the findings were represented either quantitatively, qualitatively or both according to the homogeneity between studies. Meta-analysis is a quantitative method employing statistical technique, to combine and summarized the results of studies that address the same question without major differences in its inclusion or exclusion criteria of the participants, mode of administration, doses, and duration of the intervention as well as the comparison intervention, and the outcomes assessed and the methods of their assessment. 


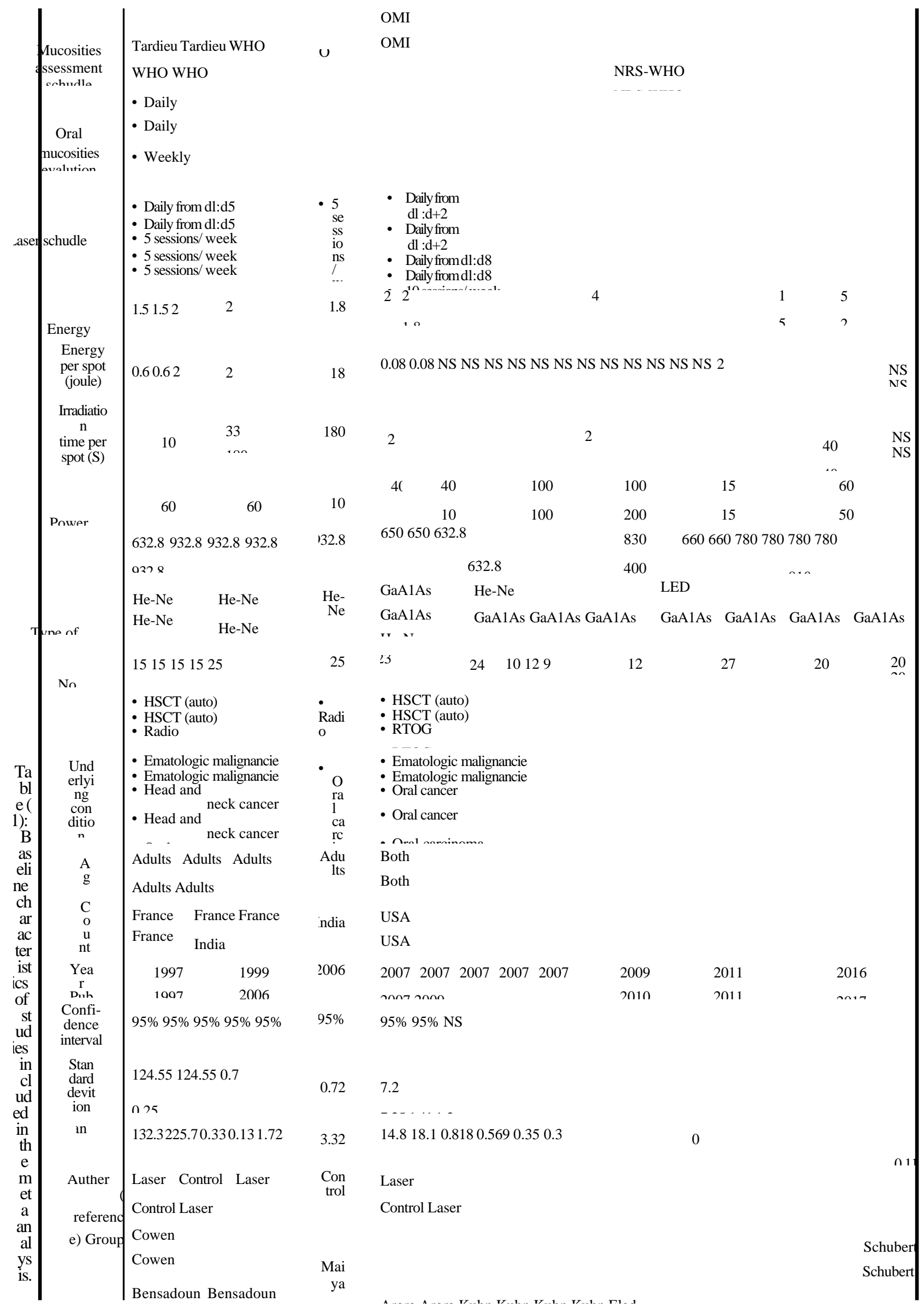


Studies must be clinically methodologically and statistically homogenous before combining its results. Confidence Interval (CI) is defined as "the range of scores within which the true score for a variable is estimated to lie within a specified probability (e.g., 90 percent, 95 percent, 99 percent)" [16].

Effect sizes with 95\%CIs were calculated if raw data were available in the studies. The effect sizes gave easy understanding of how big the treatment effect was and the clinical significance of these statistically significant treatment effects could also be justified. The effect size was "the difference between the means of outcome measures of the participants and control group". If there was no control group, the difference of the pre-and post-treatment means would be used as the participants were acting as their own controls. If heterogeneity is present, results of the studies would not be apple to be combined but would be summarized as descriptive analysis [17].

\section{Results}

This systematic review included twelve randomized controlled trials that fulfill inclusive criteria studying the effect of low level laser on pain following orofacial surgeries, published from 1997 to 2018 (Cowen et al., 1997; Bensadoun et al., 1999; Maiya et al., 2006; Schubert et al., 2007; Arora et al., 2007; Kuhn et al., 2007., Kuhn et al.; 2009; Elad et al., 2010; Carvalho et al., 2011; Machado et al., 2016; Souza et al., 2017 and Song wu et al., 2018) and studying its effect on secondary outcomes as ROM.

These studies included in meta-analysis for primary and secondary outcomes and included in descriptive analysis.

These studies included in meta-analysis for primary and secondary outcomes and included in descriptive analysis.

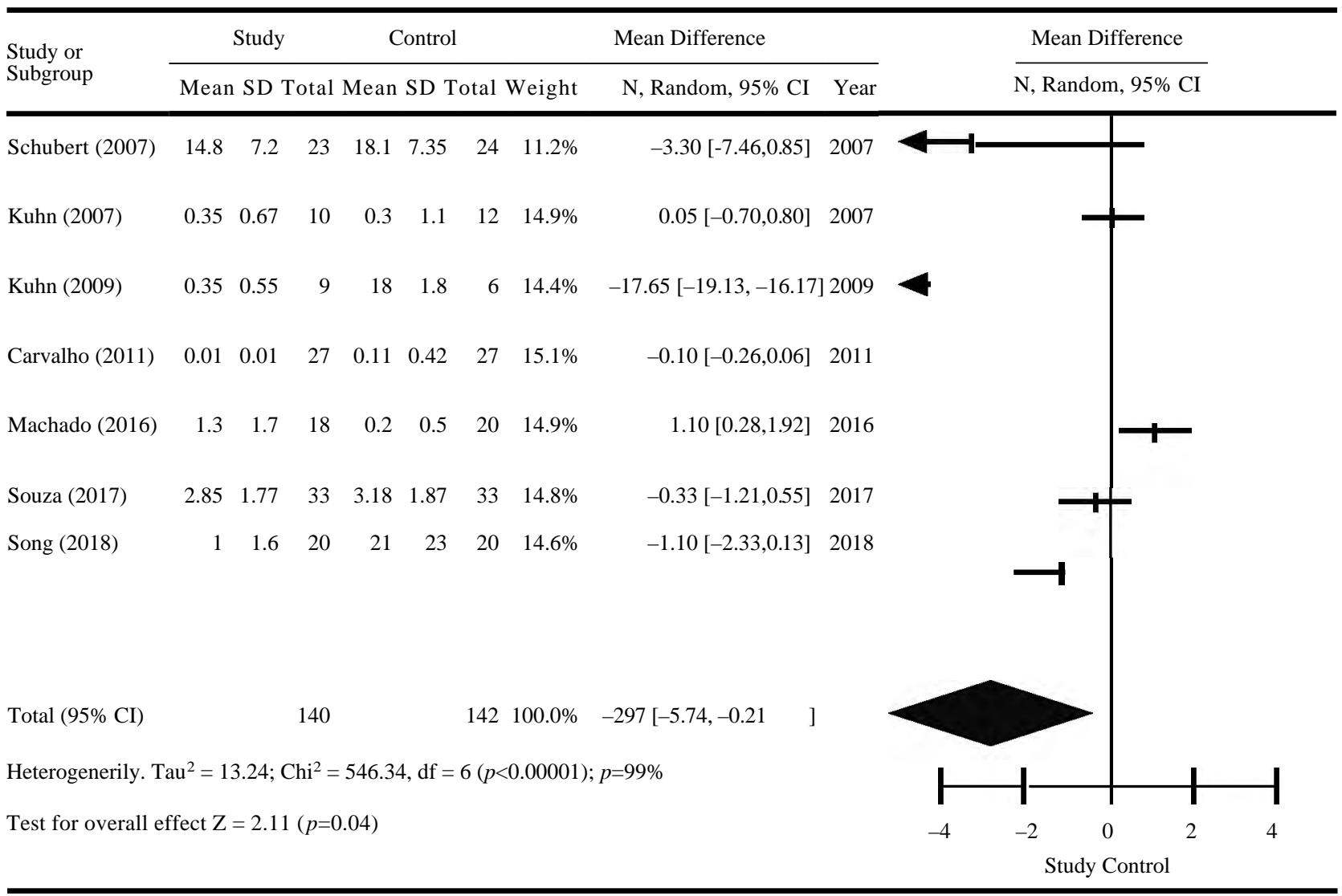

Fig. (1): Systematic review flow chart of the first literature search according to the PRISMA (preferred reporting item for systematic review and meta analyses) guidelines one study addressed both radial focused ESWT and, thus. Was listed in both categories $r$ ESWT + and f EWST. 
Table (2): The twelve selected studies for this systematic review.

\begin{tabular}{|c|c|}
\hline Study & Title \\
\hline Cown et al., (1997) & $\begin{array}{l}\text { - Low energy helium-neon laser in the prevention of oral Mucositis in patients undergoing bone marrow transplant: } \\
\text { Results of a double blind randomized trial. }\end{array}$ \\
\hline Bensadoun et al., (1999) & $\begin{array}{l}\text { - Low-energy He/Ne laser in the prevention of radiation-induced mucositis a multicenter phase III randomized study } \\
\text { in patients with head and neck cancer. }\end{array}$ \\
\hline Maiya et al., (2006) & $\begin{array}{l}\text { - Effect of low level He-Ne laser therapy in the prevention \& treatment of radiation induced mucositis in head \& neck } \\
\text { cancer patients. }\end{array}$ \\
\hline Schubert et al., (2007) & - A phase III randomized double-blind placebo-controlled clinical trial to determine the efficacy of low level laser \\
\hline Arora et al., (2007) & $\begin{array}{l}\text { therapy for the prevention of oral mucositis in patients undergoing hematopoietic cell transplantation. } \\
\text { Efficacy of He-Ne laser in the prevention and treatment of radiotherapy-induced oral mucositis in oral cancer }\end{array}$ \\
\hline Kuhn et al., (2007) & $\begin{array}{l}\text { patients. } \\
\text { - Low level infrared laser therapy to prevent radiotherapy induced oral mucositis a randomized placebo controlled }\end{array}$ \\
\hline Kuhn et al., (2009) & $\begin{array}{l}\text { - Low-level Infrared Laser Therapy in Chemotherapy-induced Oral Mucositis a randomized Placebo-controlled trial } \\
\text { in children. }\end{array}$ \\
\hline Elad et al., (2010) & - A randomized controlled trial of visible-light therapy for the prevention of oral mucositis. \\
\hline Carvalho et al., (2011) & - Evaluation of low-level laser therapy in the prevention and treatment of radiation-induced mucositis: A double- \\
\hline Machado et al., (2016) & $\begin{array}{l}\text { blind randomized study in head and neck cancer patients. } \\
\text { - Effects of oral motor exercises and laser therapy on chronic temporomandibular disorders: A randomized study with }\end{array}$ \\
\hline Souza et al., (2017) & \\
\hline Song wu et al., (2018) & $\begin{array}{l}\text { - Low-level laser therapy and anesthetic infiltration for orofacial pain in patients with fibromyalgia: A randomized } \\
\text { clinical trial. } \\
\text { - Effect of low-level laser therapy on tooth-related pain and somatosensory function evoked by orthodontic treatment. }\end{array}$ \\
\hline
\end{tabular}

\section{Discussion}

The purpose of the current review was to evaluate the effectiveness of low level laser therapy on pain following orofacial surgeries, this review includes studies published from 1997 up to 2018 and searched on baseline data base through Pub Med, PEDro, Physiotherapy Evidence Database, Cochrane library also was searched and Google web site.

This systematic review analyzed twelve randomized controlled trials, by applying strict selection criteria for inclusion, only full text articles of randomized controlled trials were included all trials met at least five criteria on the PEDro scale.

From all, eleven studies included all studies fulfill the criteria of high methodological quality which judged as strong ("yes" on 6-9 questions) according to PEDro scale.

This systematic review aimed to study the effect of Low Level Laser Therapy (LLLT) on pain following oraofacial surgeries.

A computer-aided search of baseline, PubMed, Physiotherapy Evidence Data base (PEDro), Google scholar using the words: "Laser therapy", "pain", " oraofacial surgeries", "mucositis", "oral cavity cancer". The Cochrane controlled trial register databases was undertaken from January 1997 until October 2018 for Randomized Controlled Trials of Low Level Laser Therapy (LLLT) on pain following oraofacial surgeries. A search of computerized database covering medicine, physiotherapy, allied health.
PubMed, Google scholar, Pedro and Cochrane had been searched for all randomized controlled trials that follow the criteria of the review (aged from 12-94 years and written in English language) and used laser as method of intervention, outcome measures were low level laser therapy ( $\mathrm{He} \mathrm{Ne}, \mathrm{GA}$ As and LED), post-operative pain, and orofacial surgeries. References of relevant review articles and trials were screened.

Twelve randomized controlled trials of low level laser therapy on oraofacial cancer patients were included in the review, separate data extraction sheet was done to each study describing the purpose, design, setting, sample, intervention and outcomes in a clear way, also allocation concealment, randomization, blinding and intention to treat analysis were explained if mentioned in the study. A comprehensive list of searching terms was applied and explicit inclusion criteria were developed.

Results then were classified according to the statistical difference into evidence of effectiveness and ineffectiveness; describing the intervention versus control, the outcome measure, the measuring tool if mentioned.

Conclusions on the effectiveness of low level laser therapy were based on the strength of the scientific evidence. Rating system based on the number of RCTs, their methodological quality and consistency of their results were used to provide strong, moderate, limited, and contradictory and none levels of scientific evidence. 
1- Strong evidence: Multiple relevant, high quality RCTs.

2- Moderate evidence: One relevant, high quality RCT and one or more relevant, low quality RCTs.

3- Limited evidence: One relevant, high quality RCT or multiple relevant, low quality RCTs.

4- Conflicting evidence: Inconsistent findings among multiple trails.

5- No evidence: Only one relevant low quality RCT, no relevant RCTs.

\section{Conclusion:}

The current level of evidence to support the effectiveness of low level laser therapy on pain following oraofacial cancer patients is sufficient. There are some conclusions that can be drawn from the existing evidence as follows:

1- It appears to be some evidence favoring low level laser therapy to improve oral mucositis, stomatities and oral pain.

2- It appears to be some evidence favoring low level laser therapy to improve range of motion ( overall performance) and quality of life.

High quality RCTs comparing the effect of different types of low level laser therapy on pain following orofacial surgeries which may offer more positive outcomes. Future researches need to ensure blinding as far as possible, in addition researches on low level laser therapy effectiveness on oral mucositis patients would be strengthen by the use of long term follow-up and periodical evaluation to determine the long term positive effects of low level laser therapy and also to describe the existing evidence for linkages of effects within and between different outcomes.

\section{Acknowledgment:}

We would like to thanks Dr. Mohmed Maher El-Keblawy (researcher in National Center of Research). For his support.

\section{References}

1- GAMBRILL E.: Evidence-Based Practice: Implications For Knowledge Development and Use in Social Work In A. Rosen \& E. Proctor(Eds.), Developing Practice Guidelines For Social Work Intervention (pp. 37-58). New York: Columbia University Press, 2003.

2- DRISKO J. and GRADY M.: "Evidence-Based Practice in Clinical Social Work". New York: Springer-Verlag, 2012.
3- CRAIG D., McDAID C., FONSECA T., STOCK C., DUFFY S. and WOOLACOTT N.: Are adverse effects incorporated in economic models? An initial review fzof current practice. Health Technol Assess., 13 (62), 2009.

4- THOMAS J., HARDEN A. and OAKLEY A.: "Integrating Qualitative Research with Trials in Systematic Reviews". BMJ, 328 (7446): 1010-2, 2004.

5- ABDELGHAFFAR S., ATTIA A. and ABDEL-RAOUF E.: "Essentialsof Evidence-Based Medicine", 1st ed. Higher Education Enhancement Project Fund, Cairo: pp. 1-10 \& 6: 63, 2007.

6- COTRELL R.R. and McKENZIE J.F.: Health Promotion \& Education Research Methods Using The Five-Chapter Thesis/Dissertation Model, 2005.

7- De LEEUW R.: Temporomandibular Disorders. In: De Leeuw R., editor. Orofacial Pain Guidelines for Assesment, Diagnosis and Management. 4th ed. Hanover Park, IL: Quintessence Publishing Co, Inc.; 2008. pp. 158-76. (The American Academy of Orofacial Pain), 2008.

8- GARCIA D.E., MEDINA M.G., CLAVERO T., COVA L. J., DOMINGUEZ C. and BALDIZAN A.: Nutritional characterization of six fodder species foliage with emphasis in their polyphenolic profiles. Revista Científica, FCVLUZ, 18 (2): 188-96, 2008.

9- McNEILL C.: Management of temporo mandibular disorders: Concepts and controversies. J. Prosthetic Dent., pp. 77: 10-22, 1997.

10- NECKEL C., KUKIZ P. and BIOSTIMULATION A.: Comparative study in the post-operative outcome of patients after third molar extraction. J. Oral Laser Applications, 1: 215-9, 2001.

11- RILEY J.L., 3rd, MYERS C.D. and CURRIE T.P.: Selfcare behaviors associated with myofascial temporomandibular disorder pain. J. Orofacial Pain, 21 (3): 194-202, 2007.

12- HIGGINS J.P.T. and GREEN S.: Cochrane Handbook for Systematic Reviews of Intervention Accessed in May 2011, 2008.

13- MAHER C.G., SHERRINGTON C. and HERBERT R.D.: " Reliability of the PEDro Scale for Rating of Randomized Controlled Trials". Phys. There., 83: 713-21, 2003.

14- MOHER D., COOK D.J. and JADAD A.R.: Assessing the quality of reports of randomized trials: Implications for the conduct of meta-analyses. Health Technology Assessment, 3: 1-98, 1999.

15- MOSELEY A.M., HERBERT R.D. and SHERRINGTON C.: Evidence for Physiotherapy Practice: A Survey of The Physiotherapy Evidence Database (PEDro). Australian Journal of Physiotherapy, 48: 43-9, 2002.

16- JEWELL D.: Evidence-Based Physical Therapy Practice In Guide To Evidence-Based Physical Therapy Practice 1st Ed., Jones And Bartlett Publishers, USA, 2008.

17- HERBERT R.: How to Estimate Treatment Effects from Reports of Clinical Trials. I: Continuous Outcomes. Aust. J. Physiotherapy, 46: 229-35, 2000. 


\section{تآثير العلاج بالليزر منحفض التيار على الآلم

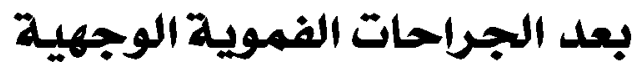 \\ (مراجعة منهجية)}

الهدف من البحث: كان الهدف من هذه المراجعة المنهية دراسة تآثير العلاج بالليز منخفض التيار على الآلم بعد الجراحات الفموية

الطرق: مراجعة منهجية للتجارب العشوائية المنطمة، آدلت دراسات معلومات فى (Pedro, Cochran) وفى باحث جوجل، المكتبة الرقمية

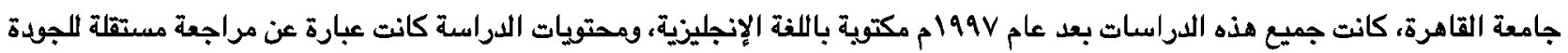
المنهجية وتعيين مستوى الآدلة (مركز الطب المبنى على البراهين).

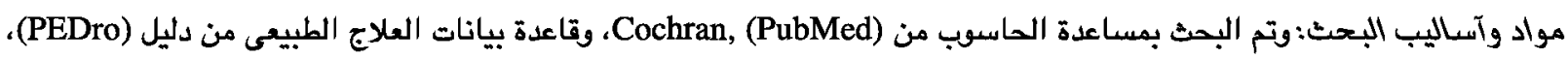

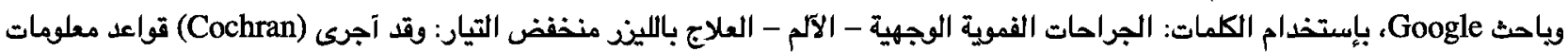

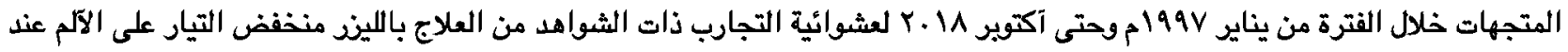

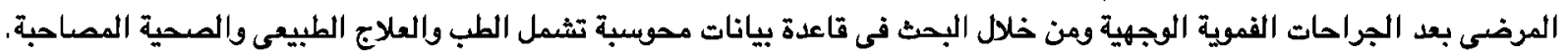
تم إستبعاد دراسات اللذة غير الإنجليزية، تم إجراء تقييم الجودة من قبل إثنين من المراجعين المستقلين، وتم حساب حسابات حجم التآثير عند تقديم بيانات كافية. النتائج:تم إختيار إثثا عشر دراسات، مدرجة فى تحليل ميتا (Meta analysis) للنتائج الآولية مثل الآلم والنتائج الثانوية مثل مدى الحركة وجودة الحياة. بعض الدرسات تفضل تاتثير العلاج بالليز منخفض التيار على الآلم عند مرضى الجراحات الفموية الوجهية ولكن غير كافية لدعم تآثيرها، وهناك آدلة تدعم تآثير الليز منخفض التيار على النتائج الثانوية مثل مدى الصئ الصركة وجودة الحياة. الإستتاجات: ا- يبدو آن بعض الآدلة لمالح العلاج بالليز منخفض التيار لتحسين إلتهاب الجراب عن طريق إلتهاب القم. r- يبدو آن هناك بعض الآدلة التى تميل إلى العلاج بالليز منخفض التيار لتصسين نطاق الحركة (الآداء العام وجودة الحياة). 